\title{
'A little learning': knowledge and health in the 18th century
}

\author{
ROY PORTER
}

Many high minded, improving physicians in 18th century England became convinced that the physician's vocation went beyond the merely clinical. It was the doctor's duty (they argued) not merely to attend individual patients but to address the ills of society at large. As Christopher Booth has shown so well, energetic figures such as John Fothergill, John Haygarth, and John Coakley Lettsom, fired by a philanthropic zeal and a non-conformist conscience, applied themselves to social reform and improvement.' They devoted their energies to good causes, from the small scale, such as the founding of dispensaries, to the visionary (for instance, the abolition of the slave trade). They passionately subscribed to the Enlightenment conviction that the advancement of knowledge - both in medical science itself, and in terms of the broader education of the public - must make its contribution to the progress of health, well being and decency. 'For observant men in the eighteenth century . . . the most tangible cause for confidence lay in medicine', concludes the eminent historian of the Enlightenment, Peter Gay: for such spokesmen, 'medicine was the most highly visible and the most heartening index of general improvement'?

Throughout 18th century Europe, philosophers, propagandists and reformers pointed to the general stimuli to betterment: the spread of trade, industry, liberty, toleration, literacy, education, and breakthroughs in technology and science. Progressive doctors naturally believed these developments would be consolidated in improvements in health. Take Thomas Beddoes, contemporary of Lettsom, radical physician, vocal supporter of the French Revolution (his activism required him to quit his chemistry chair at Oxford University), and crusader against dogmatic authority, tradition and ignorance. Enlightenment, conviction and revolutionary ebullience sparked in Beddoes a faith in a medical millennium. In his published Letter to Erasmus Darwin (1793), he proclaimed that 'a great revolution in this art [medicine] is at hand', thanks largely to discoveries in pneumatic chemistry. His own researches on gases, he explained, were about to lead to the conquest of tuberculosis. 'In a future letter,' he went on, 'I hope to present you with a catalogue of diseases in which I have effected a cure', concluding by stating his assurance that Darwin too would entertain 'hopes not only of a beneficial change in the practice of medicine, but in the constitution of human nature itself'.

Beddoes's Scottish contemporary, Dr William Buchan, was similarly optimistic about improving the people's health through 'the progress of knowledge'. The right to health, he argued, was no less fundamental than any other of the rights of man. Echoing the words of the great American physician, Benjamin Rush, he contended that ignorance was the root cause of sickness ${ }^{4}$ :

While men are kept in the dark, and told that they are not to use their own understanding, in matters that concern their health, they will be the dupes of designing knaves.

An enlightened people by contrast, attended by advanced physicians, would treasure their health effectively. Indeed, in many diseases, enlightened self-help on the part of the sufferer would be sufficient to cure: bed rest, simple diet, attention to the non-naturals, hygiene, cleanliness, and not least, trust in the healing powers of Nature. Even with venereal disease, 'in nineteen out of twenty cases, where this disease occurs, the patient may be his own physician'.5

Buchan was optimistic about the prospects of teaching the laity to protect their own health. His tenor was democratic ${ }^{\mathrm{t}}$ :

For a long while air, water, and even the light of the sun, were dealt out by physicians to their patients with a sparing hand. They possessed for several centuries the same monopoly over many artificial remedies. But a new order of things is rising in medicine, as well as in government. Air, water, and light, are taken without the advice of a physician, and Bark and Laudanum are now prescribed every where by nurses and mistresses of families, with safety and advantage. Human reason cannot be stationary on these subjects. The time must, and will come, when, in addition to the above remedies, the general use of Calomel, Jalap and the lancet, shall be considered among the most essential articles of knowledge of men. 
Yet these very doctors also entertained a more pessimistic vision. They became anxious that 'progress' was producing, not the expected improvement of health, but its deterioration. After all, who could deny that many fatal or chronic diseases epidemic fevers, rickets, tuberculosis, and 'nervous conditions' - were growing more common? Some even believed that the population of Britain was actually falling - a sure sign of biomedical as well as sociopolitical crisis. The contrast between the health of 'rude' and 'refined' peoples, many noted, did not reflect favourably upon advanced society. 'True health and vigour of body', avowed the late 18th century Scottish physician, Thomas Trotter, 'are the inheritance of the untutored savage'? Civilisation had brought with it not just (as Freud would later contend) its discontents, but its diseases too.

For one thing, doctors widely observed, the intensified cultivation of science, arts and letters was endangering health, because intellectual endeavour was a sedentary occupation that taxed the nerves. It was no accident, argued Dr George Cheyne early in the 18th century, that the first civilisation to require a well developed medical profession was that of classical Greece:

The antient Greeks, while they lived in their Simplicity and Virtue were Healthy, Strong and Valiant: But afterwards, in Proportion as they advanced in Learning, and the Knowledge of the Sciences, and distinguished themselves from other Nations by their Politeness and Refinement, they sunk into Effeminacy, Luxury, and Diseases, and began to study Physick, to remedy those Evils which their Luxury and Laziness had brought upon them.

Thus Enlightenment - the Greek Enlightenment had proved the cradle of disease. Cheyne believed the intelligentsia of his own day were similarly vulnerable $^{*}$ ( $p$ 49):

Now since this present Age has made Efforts to go beyond former Times, in all the Arts of Ingenuity, Invention, Study, Learning, and all the contemplative and sedentary Professions . . . the Organs of these Faculties being thereby worn and spoil'd, must affect and deaden the whole System, and lay a Foundation for the Diseases of Lowness and Weakness.

Second, these doctors further argued, commerce, industry, city living and affluence brought with them especially unhealthy lifestyles. Luxurious living, late rising, late nights, the anxieties of business or the idleness of the Quality, lack of exercise, over rich food, excessive drinking, and the need to shine in a competitive world dominated by fashion, weakened the body and ruined the nerves. Early in the eighteenth century, Cheyne - a society doctor who practised in Bath and London - labelled such diseases of civilisation The English malady, and called for a return to more "natural lifestyles and plainer diet (in severe cases advocating vegetarianism and abstinence from alcohol). Cheyne's books, aimed at instructing the educated public in "healthier" modes of living, proved immensely popular."

Thus enlightened doctors stumbled upon a paradox: progress in material well being and in knowledge did not improve health but jeopardised it. They sought to counter these perils by educating the public in better ways of living, as set out, for instance, in Cheyne's Essay on Health and Long Life (1724). But the irony therein was that bad advice, or good advice badly followed, would only compound the problem, for, as Cheyne's contemporary, Alexander Pope, put it, 'a little learning' could indeed be a 'dangerous thing'. Thus the growing habit amongst the 18th century educated public of poring over popular health care manuals was widely believed to be the cause of the epidemic of 'hypochondria'. Fashions in living, above all modish ideas about health care commonly picked up from medical authors themselves - were similarly held responsible for that other new and terrifying affliction, tuberculosis.

During the 18 th century, pulmonary tuberculosis became a veritable "white plague"." Around 1700, one in 10 deaths registered in the London Bills of Mortality had been due to pulmonary consumption." By its close, the figure was one in four. It had become the single largest killer of adults, a 'giant-malady', as Erasmus Darwin called it, which "destroys whole families'. '2

Why this catastrophic spread of consumption? Seventeenth century doctors such as Thomas Willis, Christopher Bennet, and Richard Morton had interpreted 'consumptions', in largely humoral categories, as the product of crass individual excess and intemperance which destroyed the constitution." Late 18 th century medical opinion, by constrast, was more inclined to look to precipitating causes endemic to civilised society at large - to changes, as Beddoes put it, "in almost every circumstance of the manner of living'. ${ }^{\text {t+ }}$

What, then, did Beddoes believe was the social pathology of tuberculosis? Two cohorts were especially susceptible. On the one hand, sectors of the labouring population. Those so poor as to suffer from absolute 'want of food' - particularly 'pot bellied' youngsters - suffered grievously ${ }^{14}$ (pp 178-9). Hardly less vulnerable, however, were sedentary operatives in workshops whose atmospheres were polluted with fibres and particles that irritated the lungs: "carpetmanufacturers, taylors and lace-weavers', 'casters of 
fine brass-work' and 'needle-grinders'. ${ }^{\text {s }}$ Such workers succumbed not through innate constitutional weakness, but because of the 'nature of the occupation', with its 'chemical and mechanical irritating substances'. They were thus 'forced into the disease' through personal 'self-neglect' and the "unconcern' of their masters."

Further choices and changes in habit, Beddoes believed, imperilled the workforce. Allured by good money in the almost feminine occupations of the cloathing manufacture', men were abandoning hard physical labour; by consequence, they became 'frequently consumptive'. Worse still, labouring people had been seduced by advertising into wearing the new, cheap, flimsy textiles - 'light cotton dresses, instead of the warmer plaid which was formerly worn'. Such fabrics, offering no protection against cold and damp, multiplied the "prevalence of colds, fevers, rheumatisms, asthmas, consumptions ${ }^{1+}$ (pp 85-89).

But fashionable society suffered even worse. Beddoes pointed an accusing finger at pernicious life styles which sacrificed health to the false gods of fashion. In their mad pursuit of the mode, the quality clad themselves in the "light dress" that was all the rage in the Revolutionary ${ }^{\circ} 9(\mathrm{~s}$. To adjust to this 'injudicious conduct', they resorted to energetic domestic heating. But the fug of stuffy rooms merely exacerbated constitutional delicacy; while dramatic temperature changes in moving from room to room or from indoors to out lacerated the lungs. Better far to wrap up in thick woollens or to wear flannel. ${ }^{17}$

But such skimpy sartorial fashions were just the tip of the iceberg of intellectual frivolity. All began with the modish "method of education' pursued in polite circles, which was almost guaranteed to turn children into weaklings, mental and physical. ${ }^{1 \times}$ Seduced by the new sensibility, parents drove their infants into precocious study, music, and accomplishments. Even girls were now packed off to be 'poor prisoners' in draughty boarding schools." Already "weak, with excess of sensibility" (p 219), adolescents were then allowed to loll on sofas, poring over improving literature and 'melting love stories, related in novels" ${ }^{\text {' }}$ (p 190). Pastimes designed to "exercise the sensibility" proved "highly enervating" ${ }^{\prime 4}$ (p 121); "fatal indolence" meant that 'the springs of their constitution have lost their force from disuse"t (p 190). All such Lydia Languishes lived under 'hazard of consumption', easily triggered by no more than a cold or chlorosis. Beddoes detailed the appalling demise of the son of James Beattie, the Scottish philosopher, who, prematurely crammed with book learning, swiftly succumbed to consumption ${ }^{1+}$ ( $p$ 124). Instead, children needed hearty outdoor exercise.

Beddoes spied a further insidious danger in seden- tariness: the solitary vice. Masturbation became the target of Georgian medical writers who exposed it not just as a sin, vice, or character weakness, but as ruinous to health, specifically because it allegedly induced wasting conditions. The more semen was conceptualised as a vital fluid, the more its unproductive onanistic waste was blamed for adolescent tuberculosis. Beddoes had no doubt that onanism, itself the product of over stimulated adolescent imaginations, was at the root of many a case of tuberculosis."

Worse still, by becoming associated with sensibility, genius and discrimination, tuberculosis was itself becoming positively fashionable. 'Writers of romance (whether from ignorance or because it suits the tone of their narrative) exhibit the slow decline of the consumptive, as a state on which the fancy may agreeably repose, and in which not much more misery is felt, than is expressed by a blossom, nipped by untimely frosts. " $"$ The preposterous idea had gained ground that "consumption must be a flattering complaint', because decline from the 'valetudinary state' was gradual, initially painless, and non-disfiguring.

In the process whereby a girl was 'manufactured into a lady ${ }^{1+}$ ( $p$ 119), parents positively encouraged over-delicacy. It was the thing to be thin, and so such creatures were allowed to turn finical eaters. Worse still, Beddoes alleged, parents who had become converts to the popular medical writings of Cheyne and his followers, were encouraging vegetarianism, convinced it purified the blood and toned up the nerves: 'There are . . . among the higher classes, some who keep their children to the fifth, or even the seventh year, upon a strict vegetable and milk diet', revealed the irate Beddoes, "believing that they thus render the constitution a signal service', and seduced by the 'false hope of rendering the blood of their children pure, and their humours mild'."2

Such modern medical heresies had to be abandoned. The Medievals could serve as a model. These sturdy swain - their gigantic armour proved their 'Herculean form' - hunted, fought, hawked, and had no 'effeminate' carriages. 'The general diet of former centuries was more invigorating', Beddoes contended, for the 'opulent of both sexes' then ate more 'animal food" ${ }^{\prime+4}$ (pp 162, 167), often breakfasting 'upon a fine beef steak broiled' - excellent for 'resisting cold" (.p 156). 'The salutary effect of animal diet in preventing Scrophula is now generally known', Beddoes insisted, 'and the mistakes of those prudent parents who imagined that by confining their children to a vegetable diet, they were purifying their blood, while, in reality, they were starving them into scrophula, are now generally recognize ${ }^{\prime+}(\mathrm{p} 166)$. As with scrofula, so consumption too was caused by 
'low diet" ${ }^{\prime 1}$ (p 166). 'Modern usages' had created 'an ebb of debility'l+ (p 171), and 'British fibre' had been sapped. The roast beef of old England was but a ghost of its former self. It was time to return to animal food $^{\prime \prime 4}$ (pp 175-6, 108).

Thus the radical chic lifestyle of the precious left them specially vulnerable: "it is upon the lilies of the land, that neither toil nor spin, that the blight of consumption principally falls" ${ }^{\prime 1 /}$ (p 43). 'Fixed . . . immoveably upon well-cushioned chairs and sofas, in hot, close apartments', they were too feeble to 'receive and digest a proper quantity of aliment'. Healthier by far were labourers who toiled hard, drank with gusto ${ }^{14}$ ( $p 125$ ) and, above all, were lusty carnivores. 'The persons most free from consumption are precisely those that consume most animal food'. Who ever saw a consumptive butcher, fishwife, or Jack Tar?

Beddoes' analysis thus underlines the ambiguous relations between the diffusion of knowledge and the improvement of health. For he believed that fashionable and impressionable society, by latching onto the half baked ideas of a fashionable physician, had helped to read itself into tuberculosis. He advocated a return, instead, to the simpler ways of a less educated era. Yet he in turn also recommended a treatment for tuberculosis which, had it become fashionable, might have added yet a further irony to the story.

For treating tuberculosis, Beddoes initially, as we have seen, put his faith in the new airs and gases with which he experimented at his Pneumatic Institution in Bristol. He also became a convert to digitalis, or foxglove - perhaps endorsing this old herbal folk cure, publicised by William Withering, because it provided an alternative to standard drug therapies. ${ }^{2+}$ But his most touted tuberculosis therapy was the 'cow-house method'. Beddoes urged consumptives to live in barns, with cattle for companions, till cured: 'stabling with cows', he reported, is 'not unpromising' 25 - while adding, for self-protection against the anticipated chortling latter-day Swiftians, 'I feel that I am preparing a feast for those who resort to ridicule'.26

The philosophy of the cow house was two-fold. The beasts themselves, and, above all, their sterceracious ferments, would yield regular, steady warmth, 24 hours a day, the best mode of central heating alive. Moreover, the volatile alkali exuded would help purify the lungs. Thus, waste products would prove not wasteful at all, but triumphantly integral to the economy of health, in a manner that would surely have given joy not just to Dr Pangloss but to that great Victorian advocate of excremental recycling, Edwin Chadwick. ${ }^{27}$

Beddoes devoted much of his Observations on the consumptive to evaluating this treatment he had "long been in the habit of recommending', even though, he confided, 'not unfrequently did I forfeit the good opinion of my patient" ( 1 23). It had enjoyed signal success, as was shown by the "narrative of Madame - who, predictably had gadded around as a bright young thing, "continuing to go out, to kecp late hours, and in every thing to live in a manner too agitated for my state of health', until her consumption worsened, when she took to the cow house. So strong was the vapour 'that every thing white which was brought in, became reddish in a very short time', and, worse, she had to endure idling gawpers who 'came to see me as an object of curiosity'. Nevertheless, she recovered ${ }^{27}$ (pp 28-34). So too did Mrs Finch - Joseph Priestley's daughter, no less - who, in letter postmarked 'Cow-House, Oct 8', explains that 'she has found a cow-house a much more comfortable abode than she had formed an idea of', though the stench was 'nauseous' and 'successive generations of flies were a considerable nuisance': 'I am', she concluded, 'more than ever a friend to the cows'"7 (p 50).

Consultations were not always so smooth, however, for certain patients 'spoke of the disgrace of being in such a situation', a 'fellow-lodger with the cows" ${ }^{177}(p$ 66). A scaled down alternative to being "closeted in a cow-house' was, however, available ${ }^{27}$ ( $p$ 66). For, Beddoes explained, 'Vessels containing the fermentable substances could easily be introduced into a warm apartment'.$^{2 x}$

Overall, Beddoes anatomised this 'giant-malady' of tuberculosis as the product of a modern economy and the modern ideology that went along with it. 'Heedless fathers and mothers are for ever guiding their sons and daughters directly into it ${ }^{\prime \prime \prime}$ (pp 100-1), for it proceeded 'from domestic mismanagement, and not from the inalterable dispositions of nature" (p 120), for 'our chronic maladies are of our own creating'th ( $p$ 98). Obsessed with the ostentation of culture, with 'dazzling strangers by the splendour of an equipage or by the lights of the understanding', modern families neglected only their health ${ }^{10}$ ( $p$ 98).

Thus alongside the medical optimism so conspicuous in the Enlightenment, sensitive doctors were also profoundly troubled by what they saw as the counter productive impact upon health produced by the spread of progressive ideas, refined culture, and modern commercial, urban values. The diffusion of medical fashions amongst impressionable people readily created health fads or spawned that morbid self-absorption about health which became medicalised as hypochondria and hysteria. The irony was that every attempt to re-educate the public - not least, Beddoes' own - ran the risk of making bad worse, and compounding confusion. Who shall say that we have resolved such problems even today? 


\author{
Wellcome Institute for the History \\ of Medicine, \\ Wellcome Building, \\ 183 Euston Road, \\ London NW1
}

\section{Bibliography}

1 Most recently, Booth C, Doctors in science and society. Essays of a clinical scientist. London: Br Med J 1987. contains several essays examining the relations between medicine, knowledge and social improvement in the 18 th century.

2 Gay P. The enlightenment as medicine and as cure. In Barber WH, ed. The age of the enlightenment. Studies presented to Theodore Besterman. Edinburgh: $\mathrm{St}$ Andrew`s University Publications, 1967: 375-86. Idem, The enlightenment. New York: Knopf, 1967-9, II, 19: for discussion, see Porter R. Was there a medical enlightenment in eighteenth century England?. British journal for eighteenth century studies, 1982; 5 46-63.

3 Beddoes T. Letter to Erasmus Darwin, MD, on a new method of treating pulmonary consumption and some other diseases hitherto found incurable. Bristol: Bulgin and Rosser, 1793: 59. For Beddoes, see D A Stansfield, Thomas Beddoes MD 1760-1808, Chemist, physician, democrat, Dordrecht: Reidel, 1984.

4 Buchan W. Observations concerning the prevention and cure of the venereal disease. London: Chapman, 1796: xxvi. See C Lawrence, William Buchan: medicine laid open. Medical history 1975; 19: 20-35. C Rosenberg. Medical text and medical context: explaining William Buchan`s Domestic medicine, Bull Hist Med 1983; 57: 22-24.

5 Buchan W. Observations concerning the prevention and cure of the venereal disease. London: Chapman, 1796: 9.

6 Buchan W. Observations concerning the prevention and cure of the venereal disease. London: Chapman. 1796: 26.

7 Trotter T. A view of the nervous temperament. London: Longman, Hurst, Rees and Orme, 1807: xvi, xvii; see also Introduction by Roy Porter to Thomas Trotter, $A n$ essay on drunkenness. London: Routledge Reprint, 1988.

8 Cheyne G. The English malady; or, a treatise of nervous diseases. London: G Strahan. 1733: 49, 56, 174.

9 For discussion see Sekora J. Luxury: the concept in Western thought, Eden to Smollett. Baltimore: Johns Hopkins University Press, 1977; H R Viets, George Cheyne, 1673-1743. Bull Inst Hist Med 1949; 23: 435, 52; Rousseau GS. Mysticism and Millennialism: 'Immortal Dr Cheyne', in Popkin RH, ed. Millenarianism and messianism in English literature and thought 1650-1800. Leiden: E J Brill, 1988: 81-126: and see also the Introduction by Roy Porter to Cheyne G. The English Malady. London: Routledge Reprint: 1989.

10 For histories of tuberculosis, see René Dubos and Jean Dubos, The white plague, tuberculosis, man and society. London: Gollancz, 1953: Bryder L. Below the magic mountain. A social history of tuberculosis in twentieth- century Britain. Oxford: Clarendon Press, 1988; Smith FB. The retreat of tuberculosis 1850-1950. London: Croom Helm, 1988; King LS. Consumption: the story of a disease. In Medical thinking. A historical preface 1982, 16-69; Kecrs RY. Pulmonary tuberculosis: a journey down the centuries. London: Baillière, Tindall, 1978; Chalke HD. Some historical aspects of tuberculosis. Public Health 1959; 74: 83-95; Burke RM. A historical chronology of tuberculosis. Springfield, Ill: Thomas, 1955: Meachen GN. A short history of tuberculosis. London: Balc, 1936; Pagel W. Humoral pathology: a lingering anachronism in the history of tuberculosis. Bull Hist Med 1955; 29: 299-308; Long ER. Tuberculosis in modern society. Bull Hist Med 1953; 27: 301-19; Milkomane GAM. The conquest of tuberculosis. London: Macdonald, 1946; Bishop PJ. Blackmore on consumption. Tubercle 1958; 39: 118-21: idem. Thomas Young and his practical and historical treatise on consumptive disorders. Tubercle 1973; 54: 159-64; historiographically valuable is Gabbay $\mathrm{J}$. Asthma attacked? Tactics for the reconstruction of a disease concept, in Wright $\mathrm{P}$. Treacher A, cds. The problem of medical knowledge. Edinburgh: Edinburgh University Press. 1982.

11 Buchan W. Domestic medicine. Edinburgh: Balfour, Auld and Smellie, 1769: 218.

12 Darwin's phrase is to be found in Beddoes T, Letter to Erasmus Darwin, $M D$, on a new method of treating pulmonary consumption and some other diseases hitherto found incurable. Bristol: Bulgin and Rosser, 1793: 61.

13 See discussion in the items listed in reference 10.

14 Beddoes T. Essay on the causes, early signs and prevention of pulmonary consumption for the use of parents and preceptors. Bristol: Biggs and Cottle, 1799: 11, 85-9; $108,119,120,121,124,125,156,162,166,167,171,175$, $176,178-9,190,219$.

15 Beddoes T. Essay on the causes, early signs and prevention of pulmonary consumption for the use of parents and preceptors. Bristol: Biggs and Cottle, 1799: 62-64: $c f$. Beddoes, Hygeia, Bristol: Phillips, 1802, 2: 32-33.

16 Beddoes T. Hygeia, 2: 24-25, 43, 98, 100-1.

17 Beddoes T. Essay on the causes, early signs and prevention of pulmonary consumption for the use of parents and preceptors. Bristol: Biggs and Cottle, 1799: 80, 128-9. On flimsy fashions, see Ewing E. Dress and undress. A history of women's underwear. London, Batsford, 1978. Beddoes also recommended the use of 'a tin footwarmer', 'manufactured of a convenient form, by Lloyd, near Norfolk Street, Strand, London': 132-3.

18 Beddoes T. Essay on the causes, early signs and prevention of pulmonary consumption for the use of parents and preceptors. Bristol: Biggs and Cottle, 1799: 90. For such aspirant middle-class life-styles, see Davidoff $\mathrm{L}$ and Hall C, Family fortunes. Men and women of the English middle classes. London: Hutchison,. 1987; Earle, Peter. The making of the English middle class: business, society and family life in London, 1660-1730. London: Methuen, 1989.

19 Beddoes, T. Essay on the causes, early signs and prevention of pulmonary consumption for the use of parents and preceptors. Bristol: Biggs and Cottle, 1799: 121. In Hygeia, 2, 11f., Beddoes gave the life history of a 
consumptive young woman, Louisa, in her own words. She had been brought up by parents who avoided gross frivolity and who had been concerned to give her a good modern education: "the graver part of light reading was our amusement and the lighter parts of science our study'. All the same, vanity was the 'ruling principle' - a vanity 'of loftier pretensions and a more solemn aspect'. 'Health was never a constant, and seldom an occasional concern. Often, because the family had other preoccupations, she had suffered from 'too long fasting'. and was often 'uncomfortable from chill'.

20) Beddoes T. Essay on the causes, early signs and prevention of pulmonary consumption for the use of parents and preceptors. Bristol: Biggs and Cottle, 1799: 118. See discussion in Jacobs, Thomas Beddoes and his Contribution to Tuberculosis, 306.

21 Beddoes T. Essay on the causes, early signs and prevention of pulmonary consumption for the use of parents and preceptors. Bristol: Biggs and Cottle, 1799: 6; cf. Sontag S. Illness as metaphor, New York: Farrar, Straus \& Giroux, 1978; London: Allen Lane, 1979.

22 Beddoes T. Essay on the causes, early signs and prevention of pulmonary consumption for the use of parents and preceptors. Bristol: Biggs and Cottle. 1799: 114. Beddoes cites the case of a 14 year old girl who "had little appetite for animal food, always preferring bread, vegetables and fruit'; Beddoes T. Hygeia, 2: 14. Valetudinarianism and food fads were often linked. When Jane Austen wanted to mock valetudinarianism, she showed Mr Woodhouse picky about food: 'an egg boiled very soft is not unwholesome'; Austen, Jane. Emma, ed Blythe R. Harmondsworth: Penguin, 1966: 54.

23 Beddoes T. Essay on the causes, early signs and preven- tion of pulmonary consumption for the use of parents and preceptors. Bristol: Biggs and Cottle, 1799: 112, 103. Beddoes reported hearing from Dr William Withering that butchers also kept themselves healthy by inhaling the steam of newly slaughtered carcases.

24 Stansficld DA. Thomas Beddoes, MD, 1760)-1808. Chemist, physician, democrat. Dordrecht: Reidel. 1984: 112.

25 Beddoes T. Essay on the causes, early signs and prevention of pulmonary consumption for the use of parents and preceptors. Bristol: Biggs and Cottle, 1799: 55. 264. On foxglove sec Aronson JK. An account of the foxglove and its medicinal uses, 1785-1985. London: Oxford University Press, 1985.

26 Beddoes T. Observations on the medical and domestic management of the consumptive. London: Longman and Rees, 18()1: 22, 23, 28-34, 50, 66, 85.

27 Finer SE. The life and times of Sir Edwin Chadwick. London: Methuen, 1952.

28 Beddoes T. Observations on the medical and domestic management of the consumptive. London: Longman and Rees, 1801: 86. Beddoes prints a letter from Dr John Barr. Mrs Finch's physician, stating that it gives me the sincerest pleasure that the cow-house has so completely suspended the progress of her disorder (28). Beddoes notes that he had offered Mrs Finch the choice between going on a sea voyage and (what might appear a very extravagant proposal) constant residence with cows". Like a good patient, she had deferred the decision to himself. "I told her, undoubtedly, residence with cows" (27). In a similar way, he had urged a consumptive man 'to try the cow-house, rather than return to Portugal' (27). 